\title{
ISOLATION AND CHARACTERIZATION OF BACTERIA ON MOBILE PHONE SCREEN FROM SOME NOVENA UNIVERSITY STUDENTS
}

\author{
Eboh. O.J., Onuoha. T and Aghanenu, A.S. \\ Department of Biological Sciences, Novena University, Ogume, Delta State, Nigeria.
}

Citation: Eboh. O.J., Onuoha. T and Aghanenu, A.S.(2022) Isolation and Characterization of Bacteria on Mobile Phone Screen from Some Novena University Students, European Journal of Biology and Medical Science Research, Vol.10, No.1, pp.1-6

\begin{abstract}
The study was to isolate and identify bacteria on mobile phone screen from some students of Novena University. Thirty samples were collected by using wet sterile swabs in transporting media to detect the presence of bacteria. A total of thirty samples per sex of students (15 males and 15 females) were collected. The swabs have been cultured on a different media in order to determine the bacteria on these devices. The study results showed that mobile phone devices from students (females and males) have been contaminated with bacteria isolates. Out of 30 samples, 13 (14.33\%) for both males and females were contaminated with Staphylococcus and Eschericha spp. The results show that Staphylococcus (53.85\%) is more prevalent than Eschericha spp. (46.67\%). It is recommended that good hygiene practices should be observed by students to avoid spread of pathogen from phone devices.
\end{abstract}

KEYWORDS; staphylococcus aureus, escherichia coli, mobile phone, screen

\section{INTRODUCTION}

Bacteria are group of organisms that are ubiquitous in nature and can occupy the environment. They grow rapidly as a result of their simple structure and genetic organization (Barer, 2007). Many have simple growth requirement and can withstand hard environmental conditions, some can adapt on environmental surfaces or on the skin of an individual (normal flora) .It also add to the economic value of the society.

Normal human bacterial flora was previously considered to be non-pathogenic and disregarded in recent years but their clinical importance as opportunistic pathogens is increasing. These organisms can cause community and hospital acquired infections, frequently producing disease when transferred from healthy individuals to susceptible hosts both direct and indirect contacts have been implicated in such instance for a variety of different organisms (Elkholy and Ewees, 2010). Mobile phones are common among student in universities which can be used to communicate for social or academic purpose, according to the technological features of dives and internet connection. Students related to health science majors use their mobile phone while performing internet hips at hospitals or clinical laboratories either to access information on their field or expertise, answer call, send text messages or take pictures during practice (Ozdalge, 2012) and (Newman et al., 2013). 
Vol.10, No.1, pp.1-6, 2022

Print ISSN: ISSN 2053-406X,

Online ISSN: ISSN 2053-4078

On the other hand, students in social science use their mobile phones when practicing or working at offices. The present use of mobile phones in different places or sites raise the opportunity for cross contamination especially into hygiene measures and sanity practices are common among students (World Bank, 2012). If pathogens are present on the surface or a mobile phone, they could be transferred to the user skin, other surfaces, or foods, where survival and growth is possible. The aim of this study was to determine the prevalence of contamination on phone screens from some Novena university students

\section{MATERIALS AND METHOD}

\section{Study Area}

The study was carried in Novena University Ogume, Delta State Nigeria. Novena University located in Ukwuani Local Government Area of Delta State.

\section{Population of Study}

The population of the study refers to the number of students of Novena University which was thirty (30) of which sample were collected from due to time and financial constraint.

\section{Sample Collection}

The samples were collected from the mobile phones of students of Novena University Ogume, using a sterile cotton swabs. The swab moistened in saline water and were rotated over the front and the back of cells phones. The devices were not cleaned before sample collection.

\section{Isolation and Identification of Bacteria}

After sample has been collected, they were transported immediately to the laboratory for culturing. The isolation was made by inoculating swab onto nutrient agar and MacConkey agar and incubated for 24 hours at $37^{\circ} \mathrm{c}$ and was subcultured on Manital agar and incubated for 48 hours at $37^{\circ} \mathrm{c}$. The identification of bacteria was made based on Gram reaction colony characterization and other biochemical test such as catalase test and coagulase test .

\section{RESULTS AND DISCUSSION}

A total of 30 samples were collected with sterile swab sticks from mobile phones screens from some students of Novena University Ogume. Out of this $13(43.33 \%)$ were infected with bacteria while $17(56.67 \%)$ were not infected with bacteria table 1

Table 1: total number of samples infected with bacteria.

\begin{tabular}{lll}
\hline No examined & No infected & Prevalence $(\boldsymbol{\%})$ \\
\hline 30 & 13 & 43.33 \\
\hline
\end{tabular}

In the study, two bacteria species were observed: Staphylococcus spp and Escherichia spp. Staphylococcus aureus had the highest prevalence of 53.85\%. 
Table 2: Prevalence in relation to bacteria species isolated.

\begin{tabular}{lll}
\hline Bacteria specie & No infected & Prevalence $(\%)$ \\
\hline Staphylococcus spp & 7 & 53.63 \\
Escherichia spp & 6 & 46.15 \\
\hline
\end{tabular}

It was observed that more mobile phone screens of males were infected (46.67\%) their mobile phone screen of female $(40.00 \%)$ with bacteria (Table 3).

Table 3: Prevalence of bacteria in relation to gender

\begin{tabular}{llll}
\hline Bacteria specie & No examined & No infected & Prevalence $(\%)$ \\
\hline Male & 15 & 7 & 46.67 \\
Female & 15 & 6 & 40.00 \\
Total & 30 & 13 & \\
\hline
\end{tabular}

Table 4: Prevalence of specific bacteria isolated according to gender.

\begin{tabular}{|c|c|c|c|c|c|}
\hline \multirow{3}{*}{$\begin{array}{l}\text { Bacteria } \\
\text { Species }\end{array}$} & \multirow{3}{*}{$\begin{array}{l}\text { Total } \\
\text { Number } \\
\text { infected }\end{array}$} & \multicolumn{4}{|l|}{ Gender } \\
\hline & & \multicolumn{2}{|l|}{ Male } & \multicolumn{2}{|l|}{ Female } \\
\hline & & $\begin{array}{l}\text { No. } \\
\text { infected }\end{array}$ & Prevalence & No. infected & Prevalence (\%) \\
\hline S. aureus & 7 & 3 & 42.86 & 4 & 57.14 \\
\hline E. coli & 6 & 4 & 66.67 & 2 & 33.33 \\
\hline
\end{tabular}

The result showed that more mobile phone screen of female students $(57.14 \%)$ were contaminated with Staphylococcus aureus while less mobile phones of male students $(42.86 \%)$ were contaminated with Staphylococcus spp (Table 4).

On the other hand, Escherichia spp contaminated the mobile phone screens of more male students $(66.67 \%)$, there is less female students (33.33\%) (Table 4).

The prevalence rate with bacteria was high (43.33\%). Staphylococcus aureus had a higher prevalence rate of $53.85 \%$ while Staphylococcus is usually on the nasal passage and skin on $15-40 \%$ healthy human. $S$. aureus is one of the most common causes of nosocomial infections, which is caused by patients own endogenous microbial flora (Arif et al., 2007). E. coli strains regularly reside in human intestine and their presence on a cell phone in some cases, phone could be infected with a very nasty strand called E. coli $0.57 \mathrm{H}^{+}$. Mobile phones get contaminated by microorganism when they are exposed to places such as hospital, toilets, hand bags and pocket. These places inhibit pathogenic microorganism, as mobile phone are rarely clean and maintained, exposing them to such places make them sources of disease transmission (Allegal, 2011). 
Vol.10, No.1, pp.1-6, 2022

Print ISSN: ISSN 2053-406X,

Online ISSN: ISSN 2053-4078

Mobile phones are one of the dirtiest things we use every day, that carry a number of bacteria, which about 7 times greater than the toilet seat. These phones operate as reservoir and carrier for the bacteria which can survive on non-living surfaces for long periods up to several months (Gunasekora, 2009).This research was compared with other studies done by Akinyemi et al., 2019 in Ogun metropolis, and it was observed that organisms like Pseudomonas aeruginosa, Salmonella typhi, Staphylococcus spp and E, coli was isolated. Staphylococcus aureus was predominant, followed by E. coli as well as the Pseudomonas and salmonella. These results were coincided with a study that was reported by Bhat et al., (2011) with the isolation of $S$. aureus and E. coli. In addition to Abdelraouf et al., (2014) who confirmed that the overall percentage of positive cultures was $71.6 \%$ most predominant isolate (with 27\%). Moreso, mobile phones of male students $(46.67 \%)$ were infected with bacteria than mobile phones of female students $(40.00 \%)$. This maybe as a result of proper hygienic measures applied by female students compare to male students.

In a similar research, a study of Emass (Sweden, 2015) University of Baghdad College of Science concluded that the ratio of contaminated mobile phones of male counterpart $(61.11 \%)$ is more than for female students $(38.88 \%)$.

\section{CONCLUSION}

Mobile phone can get contaminated and inhabited by bacteria due to improper personal hygiene practice. The resistant organism is increasing daily and mobile phones are one of the devices which are not regularly cleaned. One is prone to transfer of microbes from phones to one's body through nails and fingers. When germs are not cleaned for days or weeks from phones its results in bacterial infection like acne, pimples, other illness like cold flu, gastro-intestinal, stomach illness from touching surfaces and passing it to phones.

\section{REFERENCES}

Akinyemi, A., Atapu, O., Adetola, O., and Coker, A. (2009). The potential role of mobile phones in the spread of bacterial infections. Journal of infection in developing countries, 3(8): 628-632.

Al-Abdalalli, A.H.A (2010). Isolation and identification of microbes associated with mobile phones in Oamman in Eatern Saudi- Arabia. Journal farm, community Medical science. 17: 11-14.

Amala, S.E. and Ejikema, I.F. (2015). Bacterial associated with the mobile phones of medical personnel.Amj. Biomed. Sci. 7 (1): 26-32.

Aringemi, K. O., Atapu, A.O., Adetona, O. O and Coker, A. O. (2009). The potential role of mobile phones in the spread of bacterial infections. Journal of infections in developing countries. 3(8): 628-532.

Auhim, H.S. (2013). Bacterial contamination of personal mobile phonbes in Iraq. Journal of chemical, biological and physical sciences. An international peer reviews E-3. Journal of sciences 3(4). 2652-2656. 
Vol.10, No.1, pp.1-6, 2022

Print ISSN: ISSN 2053-406X,

Online ISSN: ISSN 2053-4078

Bhooderoma, A., Gookool, S. and Biranjia-hurdoyal, S.O. (2014). The importance of mobile phone in the possible transmission of bacterial infections in community. Journal hospital 39 (5): 965-967.

Brady, B.R.W, Wasson, A., Stirhing, I., MCAllister, C. and Wamani, N.N, (2006). The incidence of bacterial known to cause nosocomial infection on health care workers mobile phones. Journal hospital infection. 62: 123-125.

Brady, R.R., Fraser, S.F., Ohnlop, M.G., Peterson-Brown S. and Gibb A.P. (2007). Bacterial contamination of mobiles phones communication devices in the operative's environment. Journal of hospital infection (8) 397-398.

Ekrakene, T., Igeleke, C.L. (2007). Micro-organisms associated with public mobile phones along Benin-Sapele Express way. Benin city, Edo state of Nigeria. J. applied sciences res. 3: 2009-12.

Elkholy, M. and Ewiees, I. (2010). Mobile cellular phones contaminated with nosocomial pathogens in intensive unit. Medical journal, Cauro University., 5(7):243-23.

Elmanama, A., Hassona, L., Marouf, A., Alshaer, G., Abu, Ghanian E. (2014). Microbial load of touch screen mobile phones used by University students and health care staff. Journal of the Arab American University. 1(1).

Gashaim, M., Abtew, O., and Addis, Z. (2014). Prevalence and antimicrobial susceptibility pattern of bacteria isolated from mobile phones of health care professionals working in Gondar Town health centres. Internationals scholarly in research notices public health.

Gladbatt, J., Kriaf, I., Haller, T., and Milloil, V., Sith-Smith, D., Saigo, L., and Potasman, I. (2007). Use of cellular-telephones and transmission of patogens infections control of hospital and epidemiology. 28. 500=503.

Gordon, A., Richard, K., and Smith, G. (2006). Mobile and wireless communications. McGram Hill international. 17: 12-15.

Griffith, J.F., Weisberg, S.B., Arnold, B.F., Coay, Schiff, K.C., Colford, J.M., Jr. (2016). Epidemiologic evaluation of multiple alternate microbial water quality monitoring indicators at three California beaches water res. 94: 371- 81.

Illusanya, O., Adensanya, O., Adesemouno, A. and Amushan, N. (2012). Personal hygiene and microbial contamination of mobile phones in the spread of food/vendors in AgoIwoyeytwon, Ogun state Nigeria. Pakistan,journal if nutrition. 11(3): 276-278.

Karabay, O., Kocogly, E., Tahtani, M. (2007). The role of mobile phones in thespread of bacteria associated with nosocomial infection. Infect developing countries. 1(1).

Lister, Philip, Daniel, J. Wolter and Nancy D. Hansaon (2014). Antibacterial- resistant pseudomonas aeruginosa: clinical impact and complex regulation of chromosomally encoded resistance mechanisms. clinicalmicrobiology reviews. October 2009(Aug. 11, 2014).

Mcwa, M., Sharma, J., Bharhwaj, S. (2013). The role of mobile phones in the spread of bacteria associated with nosocomial infections. International journal of epidemiology and infection, 1(4):58-60.

Montefour, K., Frieded, J., Hurst, S., Helmich, C., Headley, D., Martin, M.(2008). Aeinetobacterbaumanni, anermerging multidrug. Resistant pathogen ineretical care. crit care nurse. 28: 15-25, qui 2: 26. 
European Journal of Biology and Medical Science Research

Vol.10, No.1, pp.1-6, 2022

Print ISSN: ISSN 2053-406X,

Online ISSN: ISSN 2053-4078

Patra. V., Bryne, S.N., Wolf, F.P. (2016). The skin microbiome: is it affected by UV. Induced immune suppression? Front microbial. 7: 1235.

Senbeny, P.J., Riddle, M.S., Peterson, K.(2008). AcinetobacterBaumanni skin and soft tissue infection associated with imatrauma. Clinical infectious diseases. 47: 444-9.

Singh, D., Acharya, S., Bhat, M., Roa, S.K., Pentapati, K.C.(2010). Mobile phone hygiene: potential risks posed by use in the clinics of an Indian dental school. J. dent. Educ. 7:1153-1158.

Verran, J.(2012). The microbial contaminated of mobile communication devices. J microbial biology education. 13: 59-61.

Ivnod Kumar B., Hobani, Y.H., Abdulhaz, A. (2014). Prevalence of antibacterial resistant bacteria contaminants from mobile phones of hospital in patent's Libyan J.med. 9: 25451.

\section{Declaration of Conflicting Interests}

The author(s) declared no potential conflicts of interest with respect to the research, authorship, and/or publication of this article.

\section{Funding}

The author(s) received no financial support for the research, author-ship, and/or publication of this article

\section{Ethical Approval Statement}

The research was approved by Novena University, Research and Publication committee 